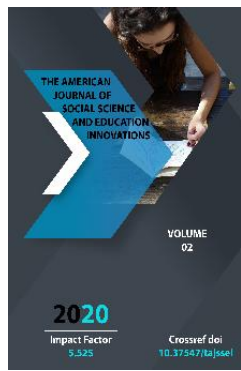

\title{
On Some Controversial Issues In The Field Of Speech Culture
}

Islamov Utkurjon Hosiljonovich

Candidate Of Philological Sciences, Uzbekistan State Institute Of Arts And Culture, Uzbekistan

Copyright: Original content from this work may be used under the terms of the creative commons attributes 4.0 licence.

\section{ABSTRACT}

The article describes issues related to speech culture and the author analyzes the researches and views of scientists-researchers on the interpretation on the problem. The field of speech culture should always be developed in accordance with its maximum function as a process of educating cultural speech of the whole nation. This should be the great ideal of the field of speech culture. It is possible to talk about such an ideal today, but its realization, that is, the desire of all members of society to master the literary language and speak correctly and fluently, culturally and expressively in another language, can come true in the future.

\section{KEYWORDS}

Dialect, culture, philology, concept, linguistics, speech culture nation, people, science, literary language.

\section{INTRODUCTION}

Speech culture is a science of perfecting people's speech. The problem of speech culture has a number of controversial aspects that have not been adequately addressed so far. It is of scientific value to study the various views expressed in the science of linguistics on these issues, to generalize them scientifically, and to make certain clarifications on the subject. These are:

1. The scope of work on the education of speech culture, it means that, the 
culture of speech implies people - does it aim to improve the speech of the whole nation (people) or does it aim to educate the speech of a certain group of the population?

2. In order to achieve a culture of speech, is it important to first develop a culture of oral speech or is it important to raise a culture of written speech?

3. Is the phenomenon of speech culture a stable, ideal phenomenon, or a changing process?

4. What is the level of demand for cultural speech, that is, the criteria for other cultural speech?

5. Speech culture and public speaking. Their interrelationships and differences.

The process of using and utilizing literary language in the process of interaction between members of a society has certain laws. The general situation there is that everyone has a natural ability to use their native language or any other language they possess according to their needs. This ability is based on the intellectual laws that are repeated in each individual of the traditions of thought that have been passed down from generation to generation for many times. Before the emergence of literary language, even in times when people thought in the language of tribes and communities or when they speak in a literary language, as well as in a certain dialect, because of intellectual abilities that they were able to achieve their goals, understand each other. This ability may be related to the fact that a person possesses a normative system of the language or form of language he speaks, and is able to comprehend it creatively.

Having mastered the laws of this language, anyone who has been able to speak from a young age on the basis of the normative

\footnotetext{
${ }^{1}$ V.P. Filin. A few words about the linguistic norm and culture of speech. Sb. VKR, №7, p. 15.
}

features of the literary language, dialect, he can speak, think in this language. But how a person knows well the language, he or she speaks depends on his or her own activities, aspirations, life experiences, and needs.

So, it is a natural objective ability for people to speak their mother tongue or another language from a young age. For this reason, the field of speech culture does not include the task of teaching people to speak in general, to communicate through a particular language. Because, as it is noted, the ability of man to speak in his mother tongue is a pre-formed natural instinct. So what is the purpose of the field of speech culture? The field of speech culture is not in the mother tongue in general, but in teaching members of the community to be able to speak a special form of the mother tongue in a literary-cultural language. A functional form of language is a literary language that is common to all of a social group, is spoken by a particular national group. For this reason, the struggle for a culture of speech is not a struggle to make culture for exchanging of ideas among people in any way of life (for example, speaking in dialects or dialects), but a struggle for the correct exchange of ideas in literary language.

It is also inappropriate to think that without a field of literary language and speech culture, people will not be able to exchange ideas or understand each other well. It is worth quoting the words of the linguist F.P. Filin: "It is a question of how to speak correctly or incorrectly in the speech with experience of any society, it must be put forward and resolved in one way or another. Prior to its emergence in scientific linguistics, the work was based on experience, "language taste", the setting of language norms was spontaneous. However, there have been no incidents that have led to the disintegration of society due to people's misunderstanding"'. 
Therefore, in general, it is inappropriate to exaggerate the speech of experts in the field of speech culture, the impact of individuals on speech activity, the role of cultural language in the lives of members of society. "Some researchers, who are the authors of pamphlets and articles on speech culture, do not care, they think that there is some irreparable danger to literary language. These are rather exaggerated considerations. Linguists must learn the language,but language has lived and can live without linguists.

However, based on the achievements of modern science, this does not mean that the struggle for a culture of speech is insignificant"'.

Linguist G.O. Vinokur noted that even an ordinary farmer has some kind of natural "speech aspiration, movement" ("speech tension") $)^{3}$.

According to E.F Petrishchev: “The approach to the facts of language is not unique to linguists. The idea of what can and cannot be said is also present in the verbal minds of sluggish people. This idea is spontaneously applied by everyone in their speech. And this is especially evident when the imaginary person is confronted with facts of language that are unfamiliar to him"4.

Indeed, for example, people who speak in the Fergana group dialects of Uzbek language have and know the specific features of the dialect, which is their native language. At the same time, he notices deviations from the norm of the native language dialect in his speech and in the speech of others who speak the same dialect. And similarly, for a person who speak in one of the Fergana dialects, there

2 V.P. Filin. This article, p 16.

${ }^{3} \mathrm{G}$. Vinokur. Language culture, $\mathrm{P}$ 168-169.

${ }^{4}$ E.F Petrishcheva. On the question of the criteria for the criteria of normativity. Sb. "Questions of the culture speech", M., Publishing house "Science, 1967, №. $p 39$. are many features indefinite to any of the Khorezm dialects or Kipchak dialects of Samarkand dialect. Therefore, that person may even consider such a situation to be a mistake. Itskovich says, "There is an intuitive notion of right and wrong in any language environment (even in a dialectal environment)"'5.

So, as long as people have the ability to master and use their mother tongue from an early age, it is natural to ask the legitimate question of who the field of speech culture is intended for. There are different interpretations of this question in linguistics, and three of them are characterized.

1. The work on the culture of speech is carried out taking into account the whole people (nation);

2. Speech culture involves only correcting the speech of an educated, intelligent people;

3. The field of speech culture works primarily to correct the speech of the younger generation.

All three views are not yet sufficiently proven in linguistics. But in some cases, there are roadto-road views on the issues raised.

The linguist $G$. Vinokur viewed about the culture of speech, this problem is a "common, universal" measure. For this reason, he considered the tasks on this issue not only to be carried out within the framework of the urban population, the intelligentsia, but also as an important education that should be carried out in the countryside ${ }^{6}$. He understood that the result of such education was to ensure that the representatives of different strata of the population possessed the norm of literary language. It is well known that to this day it is

\footnotetext{
${ }^{5}$ V.A. Itskovich. Language norm. From-in "Education", M., p. 6.

${ }^{6}$ G. Vinokur. The language culture, pp. 113, 187 and others
} 
not known to the science of linguistics that a society in which literary language and its norm are equally occupied by the whole population has existed both in the past and at present.

Consequently, it is necessary to note the functional superiority of any speech state in our speech life, which consists of a mixture of local dialects, and sometimes dialect and literary language (e.g., oral literary speech wrapped in a shell of local dialect influence or dialectal speech with literary language influence). The concept of speech culture is related to literary language in the modern scientific sense. It is understood that, as it was noted earlier, the field of speech culture is concerned with the speech of those who speak a literary language, those who have mastered and possess the literary language, and their speech activities. But even in our society, where literary language become the common property, the majority of the population speaks a local dialects, or a language that consists of some mixture of their own dialects with the literary language. According to Z.G.Karimova: "The idea of respect is a universal humanistic concept at the same time, the principle of respect appears from the national-cultural features of each nation and is expressed in etiquette expressions of this nation. For instance, concepts such as greeting, thanking, forms of manners, farewell, asking or confirmation the interlocutor's views are clear to all nations, but the ways of their implementation are interpreted differently".?

People can be divided into the following groups according to the level of their use of the Uzbek literary language:

1) persons who can speak and write normally in the Uzbek literary language;

2) persons who can write in the Uzbek literary language, but do not fully comply with the

7 Karimova Z.G. Sentence-Words And Their Grammatical Analysis (The Principle Of Respect: On The Basis Of Comparison Of Uzbek And English norms of the literary language in oral speech;

3) persons who can speak a literary language in official circles, but speak a simple language, especially in the family, which consists of a dialect or a mixture of dialect and literary language;

4) people who speak a language in which the strong influence of the local dialect is felt;

5) people who speak a literary language in which the weak influence of the local dialect (mainly in pronunciation, in the choice of certain words) is felt;

6) people who do not know the literary language well and speak their native dialect.

These types of speech expressions among the modern Uzbek population are proof that the culture of oral speech cannot be demanded from everyone. The notion that people do not know a literary language within their national language is a relative phenomenon and is used not in the sense that they do not understand it at all, but in the sense that they are not accustomed to speaking in a literary language. However, even the fact that the presence of the sixth type of people, this group makes up the majority of the Uzbek population, shows that the requirements of the culture of speech cannot be placed within the whole Uzbek nation. This is due to the fact that a certain part of the Uzbek population has not yet switched to speaking the Uzbek literary language and is not yet fully accustomed to such speaking activities. In this regard, it is appropriate to quote the views of academician Sh.Shoabdurahmonov: "Literary language is gradually squeezing dialectal speech and entering the sphere of oral speech. However, despite the daily influence of literary language, the dialectal features of oral speech are

Languages). International Journal of Research. https://journals.pen2print.org/index.php/ijr/. eISSN: 2348-6848. p-ISSN: 2348-795X. Volume 07 Issue 04. April 2020. P. 110-117 
preserved to a certain extent not only in rural areas, but also in urban areas" 8 .

Probably for similar reasons, it is a controversy that, the definition of the scope of the field of speech culture in science. For example, some researchers argue that the culture of speech works mainly for the educated, mainly for the intelligentsia: writers, poets, artists, lecturers, party, government officials, employees of departments and organizations; the common oral form of literary language - radio, television, film, speech, and speakers, educators, advocates and publicists" .

People whose dialectal speech skills are formed and hardened are middle-aged and older people in society. At this point, it is natural to ask whether the work carried out in the field of speech culture, the education of speech culture also involves the older generation.

Some scholars view the issue of speech culture as a problem mainly related to the upbringing of the younger generation. Well-known scholar A.A. Leontev, for example, it is skeptical that the correction of the speech of the older generation in general (meaning those accustomed to speaking in dialect) can be adapted to the requirements of cultural speech. He writes: "In my opinion, conscious control (correction) of language processes in the speech activity of the older generation is very problematic"10.

${ }^{8}$ The dictionary of "Dialects", T., "Science", 1972, p395

9 S. Ibrohiov. About our speech culture: Newspaper "The culture of Uzbekistan", May 16, 1969, p 3; That author. Issues of speech culture of the Uzbek national language. "Republican Linguistic Conference on Uzbek Culture of Speech Culture", Report Abstracts, "Science" Publishing House of the USSR, Tashkent, 1969, p.26
The impossibility of literaryzing the language (speech) of the older generation is largely due to the extremely stable nature of the speaking skills acquired at a young age. Some observations made by scholars on this subject lead to the following conclusion: "Probably due to the fact that in early childhood the Uzbek literary language was imitated and mastered, in some works on the Uzbek culture of speech, the question of "who" the concept of speech culture means and "to whom" was answered: "Speech culture is necessary for both forms of literary language - written (press) and especially oral (primarily for film, radio, television, theater, speech)""11. "Paying attention to the culture of speech is not just a matter of the speaker, it is a job that is required of every citizen. Our oral and written communication must meet the requirements of what we are doing"'12.

While the culture of speech is a legitimate requirement of socio-cultural life, its acquisition actually depends on the ability, cultural level, consciousness and knowledge of each individual. In this sense, it can be said that all individuals in society have achieved the same level of cultural language; it is difficult to say that all individuals are equally prepared, capable of mastering the culture of speech in terms of knowledge and cultural level. Let's look at some of them.

Linguist M.G Ferman writes: "People's speech culture is extremely strong in its speech articulatory base and other speech skills. However, this is not always possible for

10 A.A.Leontev. Answers to the question on the norm. Sb. «VKR», №6. M., Izd-vo, 2Science », 1961, p. 215216.

11 S.lbrohimov. Issues of speech culture of the Uzbek national language. "Republican Linguistic Conference on Uzbek Language and Culture" (report abstracts), T., "Science", 1969, p.

12 S.Ibrohimov. On speech culture and literary pronunciation. Tashkent, "Fan" publishing house of the USSR, 1972, page 4. 
everyone if we have to move to another articulatory speech base (in most cases, we see that linguists retain the features of the dialectsubstrate, although they are the ones who have maximum control over their speech and follow it)"13.

For the reasons that is given, most authors argue that individuals with stagnant speech skills are not included in the field of speech culture education, but that speech culture activities primarily involve the younger generation (children). Due to such factors, the role of schools and other educational institutions in the organization of speech culture remains crucial ${ }^{14}$.

As some researchers rightly point out, "Speech culture is a reflection of social culture, the culture of human society" ". But this "mirror" does not mean that everyone's speech is civilized. Also, this "mirror" does not currently reflect the cultural and speech activities of all members of society. This is due to the fact that today there are local dialects along with the literary language, along with pure literary language there is a literary speech form influenced by local dialects, there are literary speakers as well as dialect speakers.

For a person who has mastered a literary language, the level of knowledge of the norms of literary language is a relative phenomenon, because how much a person has mastered the norms of literary language is "determined by the general cultural level of the speaker"16. On this basis, the experts in the field of speech culture wrote: "Speech culture also implies that a person has achieved sufficient and high general cultural maturity"17.

\footnotetext{
13 T.S.Kogatkova. Literary language and dialects. Sat.

"Actual problems of the culture of speech", p. 107.

${ }^{14} \mathrm{We}$ will discuss this issue in more detail in the section "Speech Culture and School".

15 S.Inomxujaev, L.Xo'jaeva. The art of artistic expression.T., 1972, p.7.
}

One of the main reasons why the speech of the whole nation and all its members cannot be adapted to the requirements of cultural speech at once is related to the development of the literary language itself, the laws of change, the shifts that occur with the passage of time in the form of literary language: even, the speech of person who related to one generation is used normal, during his life these are become as abnormal - "error" later in life.

Because of this, it is inappropriate to think of the cultural state of literary language in certain periods, it means that, the culture of literary language, as something ideal for all periods. Because language, literary language itself, is a phenomenon that changes under the influence of development. In this sense, both the concept of speech culture and the pattern of cultural literary speech are not ideal, but a relative phenomenon of the speech of speakers who once spoke beautifully, exemplarily, and now speak culturally, eloquently. In this sense, for example, the speech of speakers, which was a great example of culture in the time of A. Navoi, cannot be a model of speech culture of the linguisticnormative Uzbek literary language for the XIX century. Similarly, it is difficult for anyone who wants to speak fluently in the modern Uzbek literary language to find a pattern in the past periods of this language. Just as each period has its own environment, its own language and its own style, each period will have its own cultural literary language and its own original speech culture.

Consequently, the field of speech culture cannot take into account the cultural speech education of all members of society at the same time. In this sense, cultural speech education has certain limitations, exceptions.

\footnotetext{
16 Collective. "General Linguistics". M., Publishing house. "Science", 1970, p. 556.

${ }^{17}$ Collection. "Actual problems of speech culture", $p$. 98.
} 
The field of speech culture should not be limited to those who have mastered the literary language, those who want to speak and write in it, and those who want to correct the speech of the younger generation, of course. Such a task should be considered a minimum (marginal) task for the field of speech culture. The field of speech culture should always be developed in accordance with its maximum function as a cultural speech education of the whole nation. This should be the great ideal of the field of speech culture. It is possible to talk about such an ideal today, but its realization, that is, the desire of all members of society to master the literary language and speak correctly and fluently, culturally and expressively in another language, can come true in the future. Therefore, this concept is the highest ideal of the field of speech culture, both as a task and as a reality that has not yet been realized from the point of view of today.

\section{REFERENCES}

1. V.P. Filin. A few words about the linguistic norm and culture of speech. Sb. VKR, №7, p. 15.

2. V.P. Filin. This article, $\mathrm{p} 16$.

3. G. Vinokur. Language culture, $\mathrm{P}$ 168-169.

4. E.F Petrishcheva. On the question of the criteria for the criteria of normativity. Sb. "Questions of the culture speech", M., Publishing house "Science, 1967, №. p 39.

5. V.A. Itskovich. Language norm. From-in "Education", M., p. 6.

6. G. Vinokur. The language culture, pp. 113

7. Karimova Z.G. Sentence-Words And Their Grammatical Analysis (The Principle Of Respect: On The Basis Of Comparison Of Uzbek And English Languages). International Journal of Research. https://journals.pen2print.org/index.php/ij r/. e-ISSN: 2348-6848. p-ISSN: 2348-795X. Volume 07 Issue 04. April 2020. P. 110-117

8. The dictionary of "Dialects", T., "Science", 1972, P395

9. S. Ibrohiov. About our speech culture: Newspaper "The culture of Uzbekistan",
May 16, 1969, p 3; That author. Issues of speech culture of the Uzbek national language. "Republican Linguistic Conference on Uzbek Culture of Speech Culture", Report Abstracts, "Science" Publishing House of the USSR, Tashkent, 1969, p.26

10. A.A.Leontev. Answers to the question on the norm. Sb. «VKR», №6. M., Izd-vo, Science », 1961, p. 215-216.

11. S.lbrohimov. Issues of speech culture of the Uzbek national language. "Republican Linguistic Conference on Uzbek Language and Culture" (report abstracts), T., "Science", 1969, p.

12. S.lbrohimov. On speech culture and literary pronunciation. Tashkent, "Fan" publishing house of the USSR, 1972, page 4.

13. T.S.Kogatkova. Literary language and dialects. Sat. "Actual problems of the culture of speech", p. 107.

14. S.Inomxujaev, L.Xo'jaeva. The art of artistic expression.T., 1972, p.7. 